\title{
From ecological knowledge to conservation policy: a case study on green tree retention and continuous-cover forestry in Sweden
}

\author{
Anna Sténs ${ }^{1}$ D Jean-Michel Roberge $\mathrm{e}^{2,3} \cdot$ Erik Löfmarck $^{4} \cdot$ Karin Beland Lindahl $^{5}$. \\ Adam Felton ${ }^{6}$. Camilla Widmark ${ }^{7}$. Lucy Rist ${ }^{8} \cdot$ Johanna Johansson $^{9}$. \\ Annika Nordin ${ }^{10}$. Urban Nilsson ${ }^{6} \cdot$ Hjalmar Laudon $^{8} \cdot$ Thomas Ranius $^{11}$
}

Received: 7 August 2018 / Revised: 11 August 2019 / Accepted: 16 August 2019 /

Published online: 26 August 2019

(C) The Author(s) 2019

\begin{abstract}
The extent to which scientific knowledge translates into practice is a pervasive question. We analysed to what extent and how ecological scientists gave input to policy for two approaches advocated for promoting forest biodiversity in production forests in Sweden: green-tree retention (GTR) and continuous-cover forestry (CCF). GTR was introduced into forest policy in the 1970s and became widely implemented in the 1990s. Ecological scientists took part in the policy process by providing expert opinions, educational activities and as lobbyists, long before research confirming the positive effects of GTR on biodiversity was produced. In contrast, CCF was essentially banned in forest legislation in 1979. In the 1990s, policy implicitly opened up for CCF implementation, but CCF still remains largely a rare silvicultural outlier. Scientific publications addressing CCF appeared earlier than GTR studies, but with less focus on the effects on biodiversity. Ecological scientists promoted CCF in certain areas, but knowledge from other disciplines and other socio-political factors appear to have been more important than ecological arguments in the case of CCF. The wide uptake of GTR was enhanced by its consistency with the silvicultural knowledge and normative values that forest managers had adopted for almost a century, whereas CCF challenged those ideas. Public pressure and institutional requirements were also key to GTR implementation but were not in place for CCF. Thus, scientific ecological knowledge may play an important role for policy uptake and development, but knowledge from other research disciplines and socio-political factors are also important.
\end{abstract}

Keywords Environmental history · Environmental policy · Forest biodiversity ·

Biodiversity conservation · Policy uptake

Communicated by David Hawksworth.

This article belongs to the Topical Collection: Forest and plantation biodiversity.

Anna Sténs

anna.stens@umu.se

Extended author information available on the last page of the article 


\author{
Abbreviations \\ CCF Continuous-cover forestry \\ FSC Forest Stewardship Council \\ GTR Green Tree Retention \\ MP Member of Parliament \\ PEFC Programme for the Endorsement of Forest Certification Schemes \\ SEPA Swedish Environmental Protection Agency \\ SFA Swedish Forest Agency
}

\title{
Introduction
}

The role of ecological science and the knowledge it generates in the development of environmental policy has been intensively discussed during recent decades. Within environmental research there is a persistent concern that ecological knowledge is ignored in policy processes (van Kerkhoff and Lebel 2006; Nagasaka et al. 2016; Pullin and Knight 2003; Salomaa et al. 2016; Lawrence 2017). This concern is challenged by historical studies, which find that ecological scientists can in-fact have a strong influence on environmental policy, for example in the 'greening' of forest policy and management during the 1990s (Hays 2007; Wellock 2010; Simonsson et al. 2014). Whether ecological knowledge effectively translates into policy is however likely to be context dependent (e.g. Haas 2004). Specifically, how, when and where in the process ecologists access the science-policy dialogue will help dictate their impact on conservation policy (Gulbrandsen 2008). Likewise, studies show that inclusive and deliberate policy processes can be more important for improving scientific impact, than scientific consensus (Gulbrandsen 2008). Furthermore, when economic or political stakes are high, scientific evidence is more likely to be contested during the policy process (Gulbrandsen 2008; cf. Jasanoff 2004).

Forest covers around 30\% of the global land area and hosts most of the world's terrestrial biodiversity (FAO 2016). Approximately 30\% of this land is managed for wood production, $28 \%$ is designated to multiple uses, and $13 \%$ is managed primarily for biodiversity. Over recent decades environmental forest policies were implemented to help ensure the sustainable management of production and multiple-use forests (FAO 2016). To find sustainable ways to combine forestry with conservation is however challenging for policy makers and practitioners (e.g. Puettmann et al. 2015). It is also challenging for ecological scientists who have to provide society with knowledge regarding the ecological effects of certain management methods and identify strategies for achieving best practice and balancing trade-offs (cf. Gustafsson et al. 2012; Ranius et al. 2017).

Since the mid-1900s Sweden has had an intensive production-oriented forest management dominated by even aged forestry on both private and public land. The public problematization of forestry increased dramatically in the early 1970s. Measures associated with clear-cut forestry, including the use of biocides, soil scarification and fertilization, were met with concern by a wide range of stakeholders (Simonsson et al. 2014; Enander 2007). During the last four decades forest policy declared that conservation actions should be implemented at different scales in the whole forest landscape (Mårald et al. 2017). In line with this expectation, it was suggested that both green tree retention (GTR) and continuous-cover forestry (CCF) could be used to enhance biodiversity in production forests while still allowing for the extraction of wood-based commodities (Simonsson et al. 2014; Mårald et al. 2017). After four decades of policy development, GTR experienced 


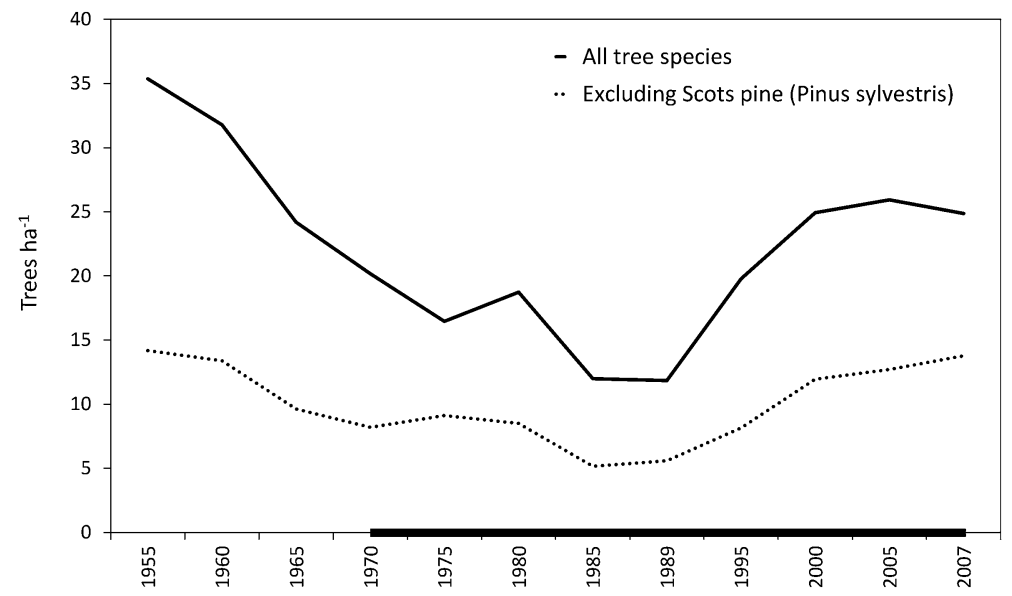

Fig. 1 Mean density of living trees (diameter at breast height $(\mathrm{DBH}) \geq 15 \mathrm{~cm}$ ) in forest stands $0-10$ years old for Sweden during the time period 1955 to 2007. Source Swedish National Forest Inventory, adapted from Kruys et al. (2013). These data are restricted to solitary trees and trees in very small retention patches $(<0.02$ ha). A separate (dashed) curve is presented for data excluding Scots pine (Pinus sylvestris), because this species is often left as seed trees for regeneration purposes. Hence, the curve excluding Scots pine may better reflect temporal trends in the long-term retention of trees specifically for conservation purposes. The thicker part of the $\mathrm{x}$-axis depicts the main period of interest for the analyses presented in the text

widespread implementation in Sweden (Fig. 1), whereas CCF remains rare, as in other parts of the world (Puettmann et al. 2015).

Several case studies in Sweden have helped clarify how different social and political factors have influenced forest policy processes and forestry's ability to adapt new management and conservation measures. Eckerberg (1987) showed that soft law, a united "forest sector culture", prioritizing rational economic forestry, and the use of large and heavy harvesters, hampered the uptake of conservation measures in forest operations in the 1980s. More recent studies have also identified historical, cultural, economic, logistical, technical and ecological obstacles to the implementation of silvicultural alternatives to clearfelling systems (e.g. Axelsson and Angelstam 2011; Simonsson et al. 2014; cf. Puettmann et al. 2015). The increased use of certain mixed-species forest alternatives has been hindered by their divergence with economic objectives, and also a need to overcome gaps in management knowledge, higher management complexity and uncertain production outcomes (Lidskog and Sjödin 2014; Felton et al. 2016).

Here we contrast and tease out the role of ecological science in the policy development regarding the implementation of GTR and CCF in a Swedish context. By so doing we compare how science translates into practice for two forestry related practices that largely overlap in their general intent (increased forest habitat availability), but nevertheless differ in terms of their management specifics, level of implementation and likely evidentiary support. Thus for our purposes GTR and CCF overlap sufficiently in context to warrant comparison, and yet are distinct enough in their essentials to provide useful contrasts and varied insights regarding the role of ecological science in policy development. We define GTR as the exclusion of living trees on the cut area from current and future harvest in even-aged management systems for biodiversity conservation purposes (Rosenvald and Lõhmus 2008). We do not consider the temporary retention of seed trees or shelterwood as 
GTR because these residual trees are usually harvested (Matthews 1989). CCF is a concept used for a range of methods of selection cuttings (Kuuluvainen et al. 2012). Here we define $\mathrm{CCF}$ as a harvest method whereby the forest canopy is maintained through time, at one or more strata, without clear felling (Mason et al. 1999; Pommerening and Murphy 2004). In contrast to GTR, CCF has long historical roots and was to a large extent implemented for economic reasons until the mid-twentieth century, after which it was increasingly replaced by clear cut forestry in many countries, including Sweden (Pommerening and Murphy 2004; Siiskonen 2007). To summarize, both GTR and CCF are expected to increase habitat availability relative to standard Swedish forestry; GTR achieves this by excluding a limited number of selected trees from production (Fedrowitz et al. 2014), whereas CCF does so by maintaining greater size and age variation among the production trees themselves (Kuuluvainen et al. 2012).

In this study we use Sweden's experience with GTR and CCF implementation to analyse how scientific ecological knowledge, pertaining to biodiversity conservation, interacts with other scientific knowledge, institutional, normative and strategic factors, to shape forest conservation policy and practice. Specifically, we address the following questions:

1. Using the published scientific literature as an indicator, how has scientific knowledge regarding GTR and CCF and their ecological effects, developed over time?

2. What is the pattern of GTR- and CCF-related policy uptake in Swedish forest governance from 1971 to 2017 ?

Based on the results from these two researched questions, we discuss the role of scientific ecological knowledge versus other socio-political factors in determining the policy uptake and implementation of GTR and CCF.

\section{Analytical framework}

The development and fate of a conservation measure can be explored by analysing the underlying policy making process. One way to conceptualize this process is the policy cycle (May and Wildavsky 1978; Parsons 1995). We used it as a heuristic device to analyse the process of societal planning and decision making, in particular to explore why some policy options were readily implemented while others were not (Jann and Wegrich 2007).

Policy making presupposes that a problem has been defined by the public, media or at least by a community of people (for example scientists) (Jann and Wegrich 2007) and that there is an expressed need for state intervention and improved measures (Jann and Wegrich 2007; Lundgren 1998; see Fig. 2, first stage). The problem definition may enter the policy cycle via written suggestions from parliament members ('motion') (Riksdagen 2019; see also Table 1). The second stage stipulates that the recognized problem is put on the agenda for serious public consideration (Jann and Wegrich 2007). For example, the potential benefits of alternative forest conservation measures are considered by an appointed commission and then transformed into policy options (Riksdagen 2019). At the third stage, problems, proposals and demands are taken up by the government and turned into a policy proposal in a bill which then is discussed in a parliamentary committee and decided by the parliament (Riksdagen 2019), i.e. proposals and decisions are made regarding which options to pursue (Jann and Wegrich 2007). At this and the subsequent stage (i.e. stage 3 and 4), we were specifically interested in the stipulated strategies for how objectives should 


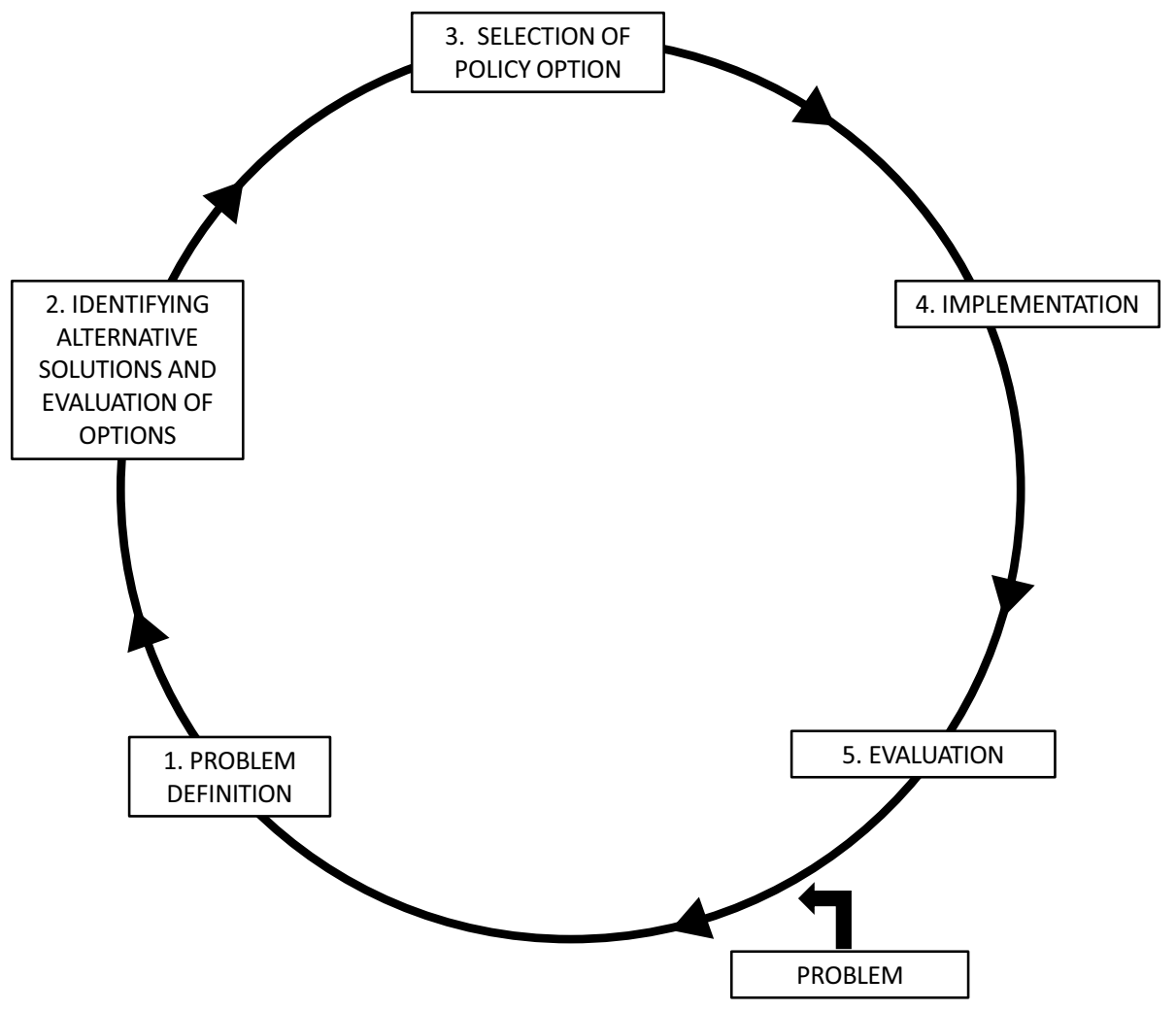

Fig. 2 A conceptual model of a policy cycle, based on Parsons (1995), is used as a heuristic device to structure the analyses of policy uptake and implementation of GTR and CCF in this study. Note that a suggested policy may go through several loops before a policy is adopted or terminated (Jann and Wegrich 2007, p 54)

be achieved. We thus investigated the choice of policy instruments used. A policy instrument is "everything a policy actor may use to obtain certain goals" (Doelen 1998) and are commonly divided into communicative (i.e. education and information), economic (i.e. subsidies and levies) and judicial instruments (i.e. law enforcement). In the literature, the instruments are normally ordered from weak to strong authoritative force, for which communicative instruments are regarded as weak, and judicial directives as strong (Vedung 1998). Optional policy instruments are also discussed at stage 2 (Jann and Wegrich 2007), but we were mainly interested in those instruments that became selected at stage three, and further developed and implemented by agencies at stage four (Fig. 2). The fourth stage of the policy cycle thus concerns implementation; the stage of execution or enforcement of a policy by the responsible institutions, organizations, and other actors (Jann and Wegrich 2007). Policy implementation thereby concerns efforts to turn stated intentions into action on the ground (Jann and Wegrich 2007). In Sweden, the Swedish Forest Agency (SFA) is responsible for implementing the Forestry Act, while the Swedish Environmental Protection Agency (SEPA) and regional county boards are responsible for implementing environmental legislation. The agencies formulate legally binding prescriptions and non-legally binding advice, building upon governmental legislation, which may involve the further development of instruments for implementation (Wallin 2017). The fifth and final stage 


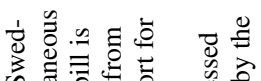

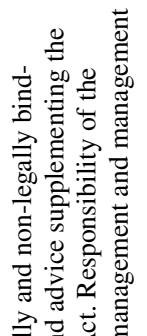

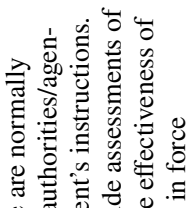

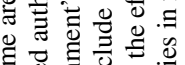

है छ

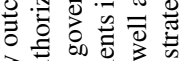

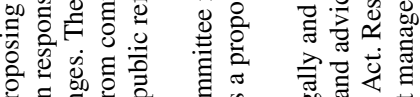

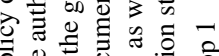

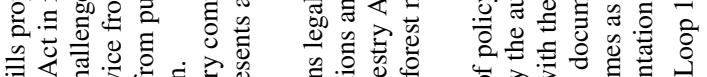

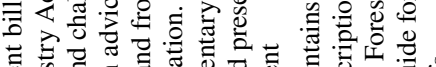

눙

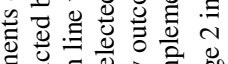

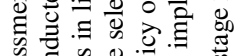

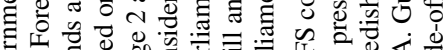

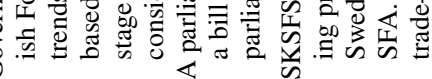

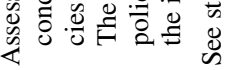

.

$\stackrel{Ð}{\Xi}$

ญ्.

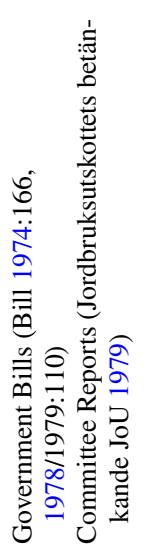

:

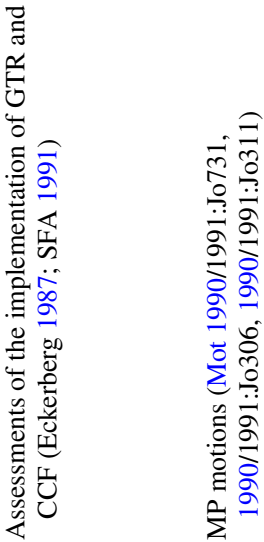

范

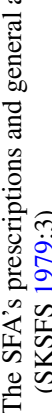

苍

를

节

.仓ํ.?

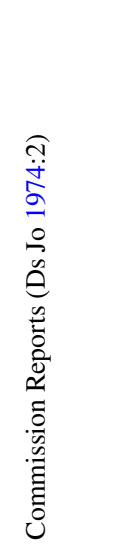

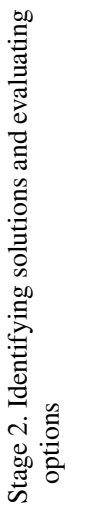

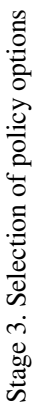

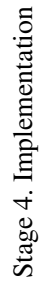

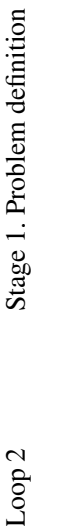

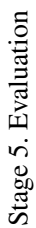




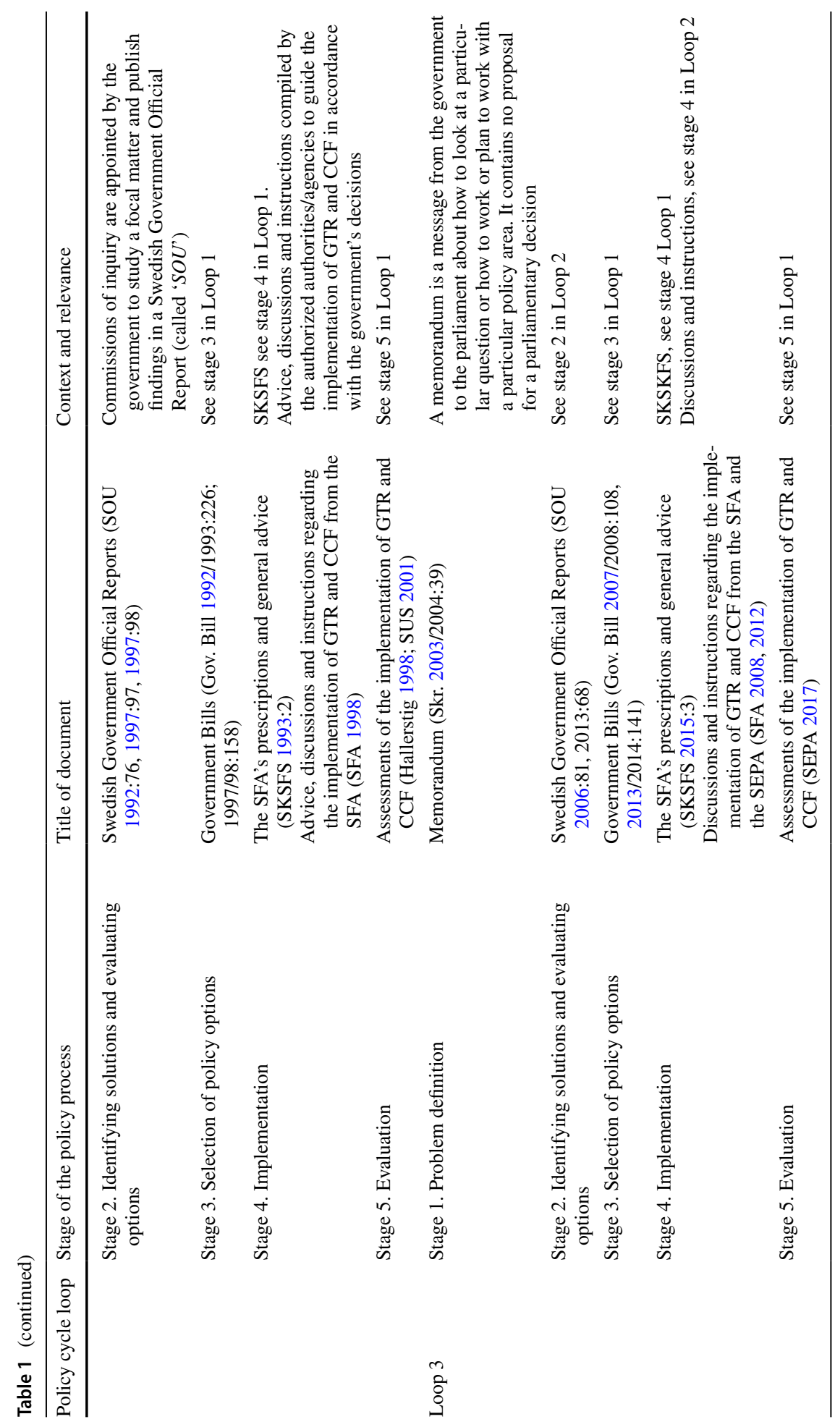


focuses on intended policy outcomes. Policy evaluation is a regular and embedded part of the political process at this stage, leading to diverse outcomes in terms of policy learning, with different implications for feed-backs and input that can potentially lead to a complete re-start or additional loops in the policy cycle (Jann and Wegrich 2007).

The model of the policy cycle has been criticized for oversimplifying the policy process, neglecting the messiness of real-world politics (Howlett et al. 2015; Jann and Wegrich 2007). However, we found that it was a useful tool to order and explore the different policy documents that addressed GTR and CCF over time (cf. Howlett et al. 2015). We also addressed the complexity of the policy process by analysing how different socio-political factors, including ecological science, fed into the policy process and interacted with each other, and how this interaction shaped the uptake of scientific ecological knowledge at each distinct stage of the policy cycle (cf. Jann and Wegrich 2007). Drawing on Lidskog and Löfmarck (2015) we addressed socio-political factors such as:

(i) knowledge from different scientific disciplines, about the needs and effects of a conservation measure. Our main focus was on the role of scientific ecological knowledge pertaining to biodiversity conservation, and how this interacted with for example knowledge regarding the production costs of forest commodities.

(ii) formal institutional factors, such as the presence of contradictory or supportive legislation or market-based certification schemes.

(iii) normative factors, such as the absence or presence of shared values and norms regarding if, how and why forests should be used. These norms may build on cultural or historical experiences and shape public opinion, networks and power relations.

Altogether, these factors contributed to whether a specific measure was regarded as

(iv) strategic by forest owners, to implement on the ground. Strategic factors refer to the necessary conditions for collective action to take place, i.e., that a critical mass needs to adopt a measure before a majority will embrace it (Lidskog and Löfmarck 2015).

We elaborate further on these factors in the discussion section.

\section{Materials and methods}

\section{Development of scientific knowledge about GTR and CCF}

To quantitatively describe the accumulation of scientific evidence, we searched for scientific publications in the Web of Science Core Collection database (WoS CC). Searching in WoS CC does not however completely cover the range of relevant scientific publications from the 1970s and 80s, as during this time relevant research within the fields of forestry and ecology were primarily written in Swedish and not published in international journals (Jonsson and Sörlin 2002). We therefore made a complementary search for "unregistered" literature (i.e. scientific literature not registered in WoS CC) in the Swedish national library database Libris (http://libris.kb.se/) using Swedish terms for GTR and CCF (the Swedish terms in the captions in Figs. 4 and 5). This search resulted in a sparse number of scientific publications, which were not included in our quantitative analysis of accumulated knowledge, but we addressed some of them in our qualitative assessment of the development of scientific knowledge regarding GTR and CCF. 
In WoS CC, for both GTR and CCF we used a search string composed of three terms separated by 'AND': the term 'forest', a set of alternative terms that depicted the focal conservation measure, and a set of alternative terms that defined the geographical scope. We restricted this quantitative search to Fennoscandian studies relevant for practices in Sweden. The search string for GTR was thus structured as follows: forest* AND ("alternative cut*" OR "alternative felling*" OR "alternative harvest*" OR "ancient tree*" OR "biological legacy*" OR "green tree*" OR "green tree retention*" OR "long-term retention*" OR "remnant tree*" OR "residual tree*" OR "retention threshold*" OR "structural retention*" OR "variable retention*" OR "veteran tree*" AND (Fennoscand* OR Scandinav* OR Finland OR Finnish OR Swed* OR Norw* OR Murmansk OR Karelia* OR Leningrad OR Petersburg). For CCF the following search string was deployed: forest* AND ("alternative cut*" OR "alternative felling*" OR "alternative harvest*" OR "clearcut free" OR "clear cut free" OR "continuous cover" OR "gap cut*” OR "gap felling*” OR "gap harvest*” OR "partial cut*" OR "partial felling*" OR "partial harvest*" OR "selection cut*" OR "selection felling*" OR "selection harvest*" OR "single tree select*" OR "uneven age*" OR "uneven size*") AND (Fennoscand* OR Scandinav* OR Finland OR Finnish OR Swed* OR Norw* OR Murmansk OR Karelia* OR Leningrad OR Petersburg). For further details regarding the search strings, see "Appendices 1 and 2".

We only retained those articles that explicitly analysed GTR or CCF in Fennoscandia, and categorized them according to their main focus: ecological effects (including biodiversity and water quality, while excluding purely silvicultural aspects such as the regeneration of crop trees and timber increment); timber production and economics (including timber increment, adaptation of forestry to climate change, crop tree regeneration, forest damage, forestry operations and monetary outcome of forest management); social values (aesthetics, recreation, cultural heritage, tourism); climate mitigation (carbon sequestration, effect on greenhouse gases); and degree of implementation (how common the method was in practice).

\section{Policy implementation of conservation practices and the role of scientific ecological knowledge vs. other socio-political factors}

To trace the trajectories of GTR and CCF in governmental policy processes we analysed policy documents from the Swedish parliament using both quantitative and qualitative methods. The quantitative analysis was based on the Swedish parliament's open data (http://data.riksdagen.se/in-english/), which contains parliamentary documents from 1971 to present. We selected series of document types which covered the period 1971-2016: written suggestions from parliament members ('motion'), interpellations, bills, chamber protocols and written questions and answers, which together amounted to almost 220,000 documents. These documents were systematically researched for the occurrence of Swedish terms depicting GTR and CCF. In the Swedish policy context, terms related to $\mathrm{CCF}$ were more clearly distinguished from alternative practices than the terms used to describe GTR. The terms used in the search for policy documents handling GTR were therefore more likely to encompass additional aspects of forest conservation than just the retention of green trees (see the Swedish terms in the captions in Figs. 4 and 5). To ensure that the policy documents actually described green tree retention, we ran a qualitative check of the documents, and made sure that this specific practice was being referred to, before including it in the results. 
The data obtained from the quantitative analysis was used to identify years and parliamentary documents where the GTR and CCF terms were mentioned most frequently. The result of the quantitative analysis indicated the existence of formative periods and several loops in the policy cycle regarding the policy uptake and implementation of GTR and CCF during the time period studied, each of which ended with an evaluation of current policy.

In order to analyse the policy development of GTR and CCF in the different stages of the loops in the policy cycle, we then used qualitative analyses of the parliamentary documents from the formative periods identified above (see Table 1) and of subsequent documents connected to the problematisation and dissemination of policy. To identify the first stage, 'problem definition', we analysed motions raised by MPs and memorandums addressing problems with existing forest management. To identify the second stage, where solutions and options regarding a problem are discussed and evaluated, we analysed commission reports addressing the pros and cons with GTR and CCF. Government bills were used to identify and analyse stage three in the policy cycle, since these documents contain the government's recommendations to parliament regarding which management methods should be used, and which policy instruments should be obtained for implementation (Riksdagen 2019). To identify and analyse stage 4, 'implementation', we moved beyond parliamentary documents to analyse documents with prescriptions, advice and information regarding GTR and CCF published by the agencies responsible for policy implementation; the SFA and the SEPA. Finally, parliamentary documents and agency reports were used to identify stage 5 of the policy cycle, the published evaluations of GTR and CCF. These were mainly identified via the parliamentary documents and collected from the agencies' websites. Official evaluations are normally conducted by the authorized authorities/agencies in line with the government's instructions. Regarding GTR, the first evaluations were however initiated and conducted by a researcher within the academy (Eckerberg 1987). Altogether, we analysed 30 documents from the Swedish government, the academy, SFA and SEPA, representing different stages and loops in the policy cycle (Table 1).

The results section presents the loops of GTR and CCF in the policy cycle as a chronologically structured narrative based on the quantitative and qualitative analyses of the different policy documents. To find out which ecological scientific knowledge influenced the policy processes over time, and how it did so, we searched the documents for references to research addressing ecological knowledge on GTR and CCF. In this way we found which peer-reviewed ecological literature, or other literature, was used in the policy process at different stages in the policy cycle. We also assessed the quality of the ecological knowledge that was used in the policy processes by distinguishing the degree to which it addressed general and theoretical knowledge or applied specific empirical knowledge about the effects of GTR and CCF on biodiversity (cf. Ranius et al. 2017). Furthermore, we looked for expressions of other scientific, institutional and normative considerations within the policy documents. These expressions are included in the narrative section of the results. Their effects on the policy cycle, i.e. whether these different factors hampered or enabled the implementation process is then further developed in the discussion. 


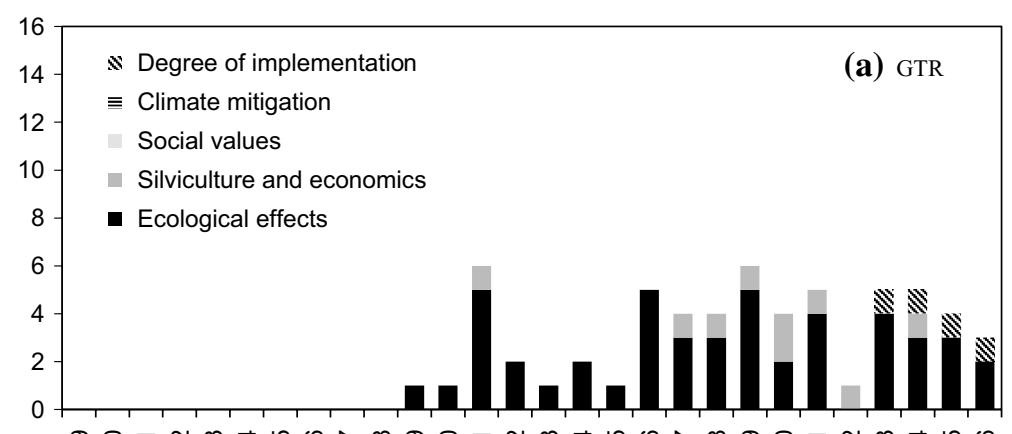

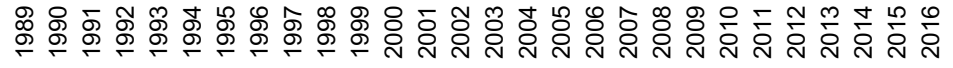

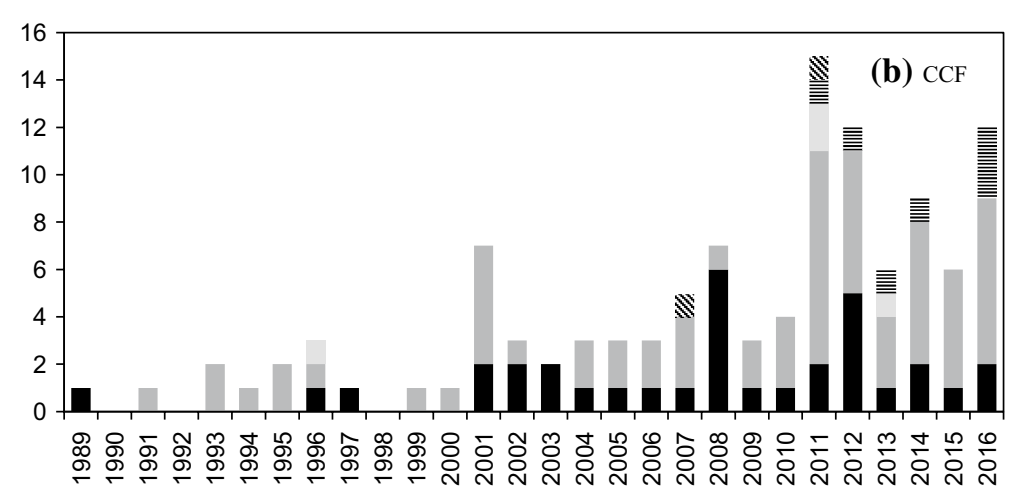

Fig. 3 Development of the body of scientific literature about a green tree retention (total number of publications $=52$ ) and $\mathbf{b}$ continuous-cover forestry (total number of publications =94) in Fennoscandia. Note: one paper may contribute to several of the topic categories, so the total number of observations in the graphs is higher than the number of publications. Six publications addressed both GTR and CCF and were included in both categories. Data stems from our search in Web of Science Core Collection (WoS CC)

\section{Results}

\section{Development of scientific knowledge over time}

The idea of GTR was presented in scientific literature already in the 1970s and developed in the 1980s (Ahlén 1977; Franklin 1989). The specific term "green tree retention" appeared for the first time in the WoS CC in 1996 (North et al. 1996) but was found in non-registered Fennoscandian scientific literature around 1990 (e.g. Esseen et al. 1992). Empirical scientific knowledge about the ecological effects of GTR in a Fennoscandian context can be traced back to 1999 in WoS CC, and papers were published in small numbers (2-3 papers per year) since 2001 (Fig. 3a). The majority of the scientific papers about GTR dealt with ecological effects ( 45 of 52), while only nine addressed silviculture and economic effects. Four papers dealt with the level of GTR implementation, whereas no papers addressed climate change mitigation or social aspects. Eight papers addressed more than one aspect and combined ecological effects with timber production and/or economic aspects and level of implementation. 


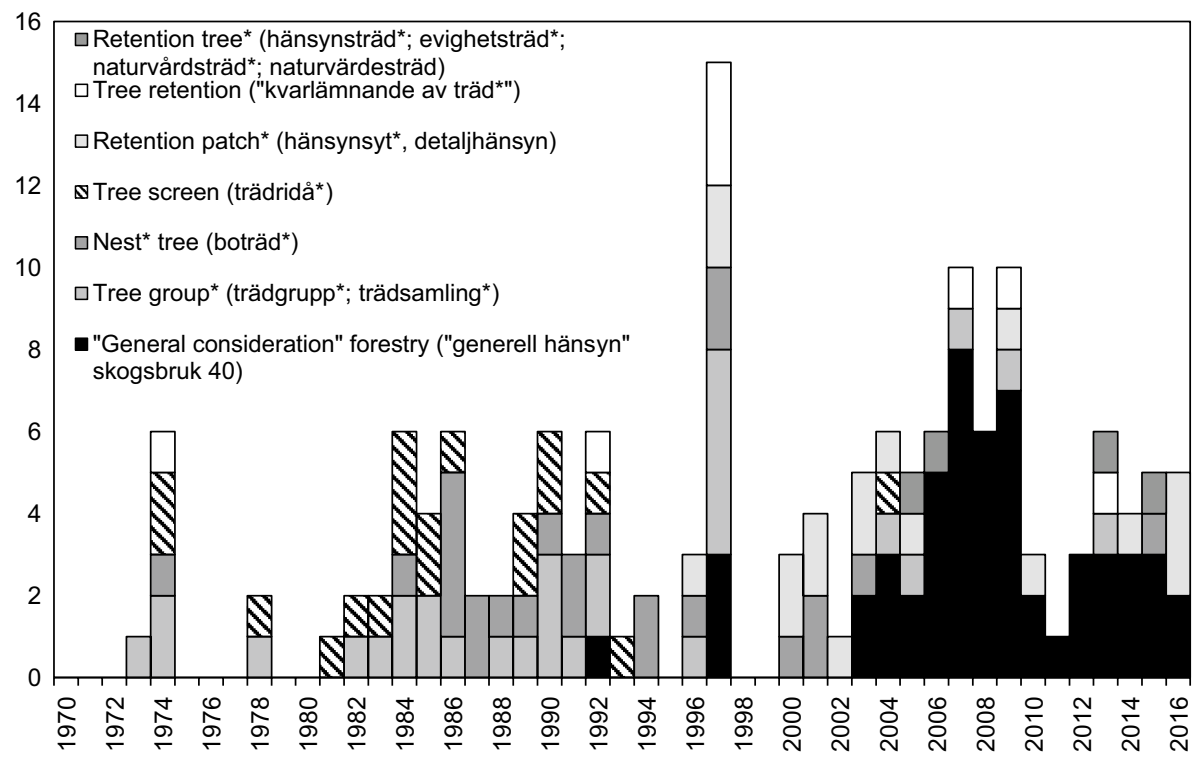

Fig. 4 Number of documents originating from the Swedish parliament that used terms related to "GTR" (see legend) in documents from the Swedish parliament, 1971-2016. Note: One document may use more than one term, and therefore the total number of documents is lower than the number of observations (total number of observations $=157$ )

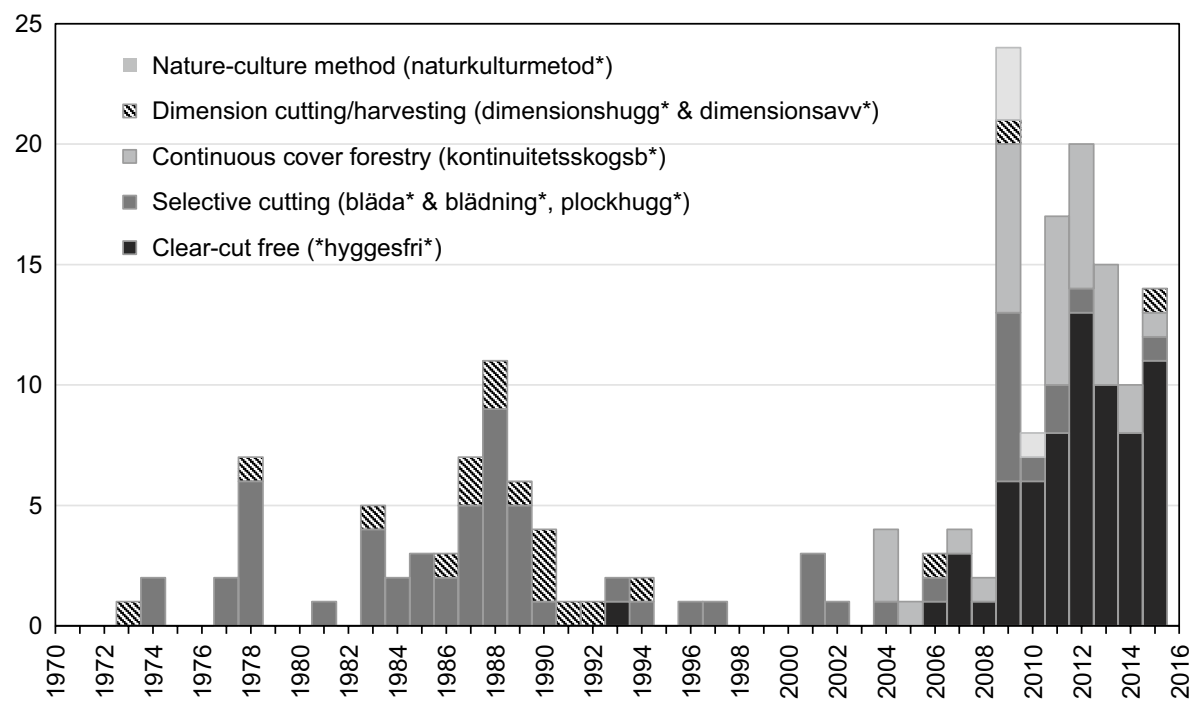

Fig. 5 Number of documents originating from the Swedish parliament that used terms related to "CCF" (see legend) in documents from the Swedish parliament, 1971-2016. Note: One document may use more than one term, and therefore the total number of documents is lower than the number of observations (total number of observations $=188$ ) 
The CCF concept appeared in the peer-reviewed scientific literature, registered in WoS $\mathrm{CC}$, in the late 1980s. Over the years the number of publications about CCF in Fennoscandia exceeded those of GTR. Empirical scientific knowledge about the ecological effects of CCF in a Fennoscandian context was published already in 1989 (Fig. 3b). In the following years the focus was however on silvicultural and economic aspects rather than ecological: 32 of the 94 papers dealt with ecological effects of CCF, whereas 61 addressed silviculture and economic aspects. The topics were also more diverse compared to GTR as papers dealt with climate change mitigation (5), social aspects (4) and the level of implementation (2) (Fig. 3b). Six papers addressed more than one aspect, and often combined ecological effects, timber production and/or economic aspects and social values.

\section{Policy implementation of conservation practices and the role of scientific ecological knowledge versus other socio-political factors}

Our quantitative analysis of documents from the Swedish parliament showed that certain years stood out as important, either for GTR or CCF. These included 1974, 1978, the late 1980s, 1997 and the 2010s (Figs. 4 and 5). Looking at the documents underlying these numbers revealed that the policy debate about GTR and CCF appeared when major governmental forest policy investigations or bills were launched by the parliament (1974, 1978, 2008), when the public debate about forestry was intense (1980s), and when existing policy was under evaluation (mid 1980s-1990 and late 1990s) (cf. Bush 2010; Mårald et al. 2017; Simonsson et al. 2014). Based on our analysis we suggest that GTR and CCF policy underwent three loops in the policy cycle since the early 1970s. The following sections present our analysis of these three loops, including their different stages.

\section{First loop: problem definition and evaluation of options}

In the awakening of environmental criticism against industrial forest management in the early 1970s, members of parliament shared concerns that clear-cuts led to impoverished ecosystems and in the long run, unsustainable forestry. They called for better knowledge about the effects of modern forestry and a review of current forest policy (e.g. Mot. 1971:1002; Mot. 1972:146). Two commissions were introduced to inquire the environmental impact of Swedish forestry, identify solutions and evaluate policy options, one of which focused on the areal extent and effects of clear-cuts (Ds Jo 1974:2). In 1974 the investigators presented a solution whereby environmental considerations would be applied during forestry operations. It was also proposed that legally binding requirements to do so could be included in the Swedish Forestry Act (Ds Jo 1974:2).

Both CCF and GTR were on the agenda as plausible conservation measures in this regard, but CCF was considered old-fashioned and not suitable for use in Swedish forest conditions (Ds Jo 1974:2). A recurring concern was that CCF could not sustain a high level of biomass production and thus would harm the ever-increasing demand for sawn timber and pulp wood from the forest industry. It was even argued that large-scale CCF was negative for biodiversity since it would generate an "unsuitable uniformity" in the forest landscape, i.e. that a landscape managed with CCF would result in less variation and habitat diversity than a landscape managed with clear-cut forestry (Ds Jo 1974:2). Clear-cuts were promoted as biologically adequate and an economic necessity by the commission. Leaving green trees close to residential areas, popular laybys, and scenic routes was suggested as a means of taking into consideration aesthetic and recreational concerns, while habitats such 
as mires, rocky impediments, and areas close to water could be taken into consideration for ecologic reasons (Ds Jo 1974:2).

The commission based its statements on hearings with ecological scientists and previous official investigations (Ds Jo 1974:2) for which ecological scientists had worked together with other scientists and civil servants to map forestry's impact on the environment (SEPA 1972). Ecological knowledge was thus informing the policy process at this stage of the cycle. In particular threatened bird species and their dependence on old trees and forest stands were discussed using support from scientific references (Ds Jo 1974:2; for detailed references see SEPA 1972). Yet, national economic and aesthetical concerns dominated the commission report and its proposals (Ds Jo 1974:2; cf. Simonsson et al. 2014).

\section{First loop: selection of policy options, implementation and evaluation}

Selection of policy options, implementation and evaluation were the next stages in the policy cycle (stage 3, 4, and 5 in Fig. 2). For GTR, the Social Democratic government suggested 'enforcement by law' as their policy instrument in 1974, i.e. a judicial approach (Gov. Bill 1974:166). The Swedish Forestry Act prescribed that single or groups of trees, screens of trees, and nesting trees for birds should be left on clear-cuts for conservation purposes (SFS 1974:1026). From 1979, these prescriptions were to be implemented by all forestry operations, regardless of forest ownership and without economic compensation. These considerations were mainly supported using aesthetical rather than ecological arguments (SKSFS 1979:3, $12 \S$ and $14 \S$ ).

In contrast, CCF was met with skepticism, because it appeared to be inconsistent with regulations that final harvest should "be conducted in a manner that is appropriate for the regeneration of new forests" (JoU 1979; also Gov. Bill 1974:166). CCF was essentially banned in 1979, as the Swedish Forestry Act stated that final harvest had to be conducted as "...clearfelling with or without shelterwood or seed trees." (SKSFS 1979:3, p. 26). The only exception was in subalpine areas, where CCF was allowed due to harsh climatic conditions (SKSFS 1979:3, see also Gov. Bill 1978/1979:110; JoU 1979).

In addition to legislation, communication and education were soon added as instruments to implement the principle of GTR in Swedish forestry. At the implementation stage, ecological scientists initiated the co-production of educational handbooks with the responsible agencies, the SFA and the SEPA to make ecological knowledge intelligible for policy makers and end-users. In the handbooks CCF was also supported, but only with respect to its application in sensitive areas, e.g. mountainous forest. The books reported on the state and trends in forest biodiversity, mainly through the presentation of early versions of national red lists of threatened species (Ahlén 1977; Ahlén et al. 1979; Ingelög 1981; Ingelög et al. 1984; Ehnström and Waldén 1986). Severe knowledge gaps were acknowledged, including a lack of scientific knowledge about species habitat requirements (Ingelög 1981; Ehnström and Waldén 1986). The limits of scientific knowledge regarding biodiversity were explained as being: "often dependent on analogy-based assessments based on a few well-researched species, particularly those of economic importance." (Ehnström and Waldén 1986, p. 9). Hence, ecological scientists indirectly criticized forest research for being steered by normative economic interests (cf. Ingelög 2007).

Evaluations of the implementation of GTR, conducted by authorities and by forest policy researchers in the mid-1980s, showed that only three out of five clear-cuts complied with the Forestry Act (Eckerberg 1987). Implementation and evaluation activities continued between 1986 and 1991 (SFA 1991). Meanwhile, forest companies outlined their own 
GTR policies drawing upon results from forest-sector based research and education projects which aimed to further elaborate on methods to increase the uptake of existing GTR policy (Lennartsson pers. comm. 2019). Public authorities supported these efforts with additional inventories and evaluations (e.g. SFA 1991). New educational handbooks that addressed nature conservation were also produced, which included information on retention forestry (e.g. Persson et al. 1990; Aldentun et al. 1991).

\section{Second loop: problem-definition and evaluation of policy-options}

After completing one loop, problem formulation and evaluation of policy options took place again. As a result of knowledge regarding GTR uptake rates and increased pressure from the public and environmental movements, political interest in GTR and CCF increased in the mid-1980s (see Figs. 4 and 5). Different groups, including ecological scientists, raised concerns about decreasing biodiversity in Swedish forests, especially due to oldgrowth forests being replaced by commercial Norway spruce and Scots pine stands (e.g. Ingelög and Lennartsson 1991; cf. Simonsson et al. 2014). Biodiversity loss was increasingly stated as the key problem that needed to be addressed (e.g. Mot 1990/1991:Jo731, 1990/1991:Jo306, 1990/1991:Jo311). Ecological scientists pleaded for stronger environmental legislation, specifically demanding a more extensive preservation of forests. Furthermore, they recommended stronger regulations of GTR, including the retention of ten large trees ha ${ }^{-1}$ (Ingelög and Lennartsson 1991). This number was not based on scientific evidence, but on negotiations between ecological scientists and the forestry sector (Lennartsson, pers. comm. 2019).

Following these debates and development in the sector, an all-party governmental investigation was initiated in 1990 (published in 1992), which suggested both the deregulation of forestry, and concurrently, to give equal importance to environmental and production objectives in forest policy (SOU 1992:76). In order to equate environmental and production goals, the commission suggested that larger areas of forest should be set aside as reserves, and that environmental considerations should be practiced on productive forest land. Environmental considerations should consist of GTR and dead wood retention at final harvest. These actions were presented as a way to increase the amount of old and deciduous trees in production forests and thus help sustain biodiversity. Hence, GTR was indirectly suggested as a prerequisite for the success of the proposed policy objectives (SOU 1992a, b:76). In addition, $\mathrm{CCF}$ resurfaced in the evaluations of potential policy options. The researchers that advised the commission explicitly discussed the potential of practicing $\mathrm{CCF}$ in some spruce-dominated forests on a fraction of approximately 2-3\% of the Swedish forest land area. The recommendation was to combine timber production and conservation by preserving large trees and leaving unharvested patches, thus combining CCF with GTR (SOU 1992a, b:76, bilagor II). These recommendations built on the few scientific publications available which addressed silvicultural and ecological effects of CCF (see Fig. 3), but the policy document did not refer to them explicitly (SOU 1992a, b:76, bilagor II).

\section{Second loop: selection of policy options, implementation and evaluation}

The Swedish Forestry Act was amended in 1993. A central change was the deregulation of forestry and the adoption of equal environmental and production objectives, which was consistent with the preceding commission's suggestions (Gov. Bill 1992/1993:226). The intention of greater freedom was that it would lead to a diversity of management practices, 
and thereby improve biodiversity. This was because the reform allowed a wider range of alternative harvesting methods, including methods consistent with CCF, on a limited proportion of forest land area (Gov. Bill 1992/1993:226, 58). Furthermore, GTR was explicitly acknowledged: "Shrubs, solitary trees or tree groups must be retained at all harvests ..." (SKSFS 1993:2, p. 25, our translation). The number of trees retained was not specified, but in an effort to improve implementation, the SFA developed a control instrument, 'Polytax', ${ }^{1}$ to assess the quality of forestry operations. The Polytax instructions stated that at least 5-10 green trees ha ${ }^{-1}$ (depending on clearcut size) should be retained at final harvest (SFA 1998), which was largely consistent with previous recommendations from ecological scientists (Ingelög and Lennartsson 1991).

The more precise legal requirements enhanced the implementation of GTR in the 1990s. The legal prescriptions were however "soft" as they lacked sanctions and were thereby regarded as too weak by the environmental movement (Simonsson et al. 2014). The environmental movement started negotiating solutions that were separate from the formal policy cycle as an alternative means of handling conflicts and forming agreements with forestry actors. As a result, the FSC (Forest Stewardship Council) was established in the mid-1990s, initiating a market-based instrument for conservation implementation which promised economic rewards for those forestry actors who met the criteria of the FSC certification standard (Johansson 2013). By requiring the retention of ten trees per hectare, the FSC certification standard replicated the GTR target in Polytax, and thereby strengthened GTR policy. In contrast, CCF was not required by the FSC standard (FSC 2010a).

In the late 1990s, the government evaluated the effectiveness of the 1993 forest policy. It concluded that GTR was conducted on $74 \%$ of inventoried final-harvest sites. This was not considered sufficient and further education of all forest sector actors was deemed necessary to increase GTR implementation (Hallerstig 1998). Parallel to this evaluation, the government investigated demands to increase the use of forest reserves, re-structure environmental legislation, and to launch a system of national Environmental Quality Objectives, several of which were relevant to forest biodiversity conservation (SOU 1997:97, 1997:98).

In 2001, a second evaluation of the forest policy of 1993 recapitulated the need for alternative forest management approaches to conserve biodiversity. The evaluators stated that the share of forests that had never been clear-felled was ever decreasing in Sweden. There was a particular concern over the loss of biodiversity when these forests were clear-cut (SUS 2001).

\section{Third loop: problem definition and evaluation of policy options}

The outcomes of the second policy evaluation in 2001, in combination with new environmental policy and public debates, spurred a third policy loop. Ecological science had contributed directly to the problematization with discussions about what was required for successful biodiversity conservation in forests (e.g. Angelstam and Andersson 1997; Gärdenfors 1997). Their reasoning built on reports and scientific publications that addressed nature conservation, but not on publications focused on GTR or CCF (Angelstam and Andersson 1997; Gärdenfors 1997).

\footnotetext{
${ }^{1}$ Polytax was a common name for inventories in the forests carried out by the Swedish Forestry Agency (Bergqvist et al. 2011).
} 
Based on the 2001 evaluation, the government stated that 'never clear-cut forests' were of special value to biodiversity, and therefore empirical data regarding management alternatives, including CCF, was requested (Skr. 2003/2004:39).

The use of CCF in suitable areas was again suggested during subsequent assessments. In 2004 and 2005 the SFA started a project to develop methods to identify forests of long continuity and manage them with CCF (SFA 2004, 2008). In 2008 the agency concluded that $\mathrm{CCF}$ could be used as a complement to clear-fellings on a limited portion (5-10\%) of Swedish forested land (SFA 2008). Furthermore, CCF was a suggested alternative in forests where nature conservation, recreation, or conflicting demands prevailed, e.g., reindeer husbandry and cultural heritage. Possible obstacles to implementation included lower economic returns (10-35\%), insufficient regeneration, and conflict with the Swedish Forestry Act. Key knowledge gaps were also highlighted, including how CCF managed forests would develop through time, and how to handle case by case evaluations of CCF suitability and legality (SFA 2008).

Researchers with an expertise in silviculture and biodiversity, respectively, were included in the project group (SFA 2008). An analysis of the scientific literature used in the report, showed that two publications from our list derived from WoS CC on CCF were cited, and these focused on the silvicultural and economic effects of CCF (Andreassen and Yen 2002; Granhus and Fjeld 2001). In another project, initiated by the SEPA, scientists, including ecologists, synthesized knowledge about land use, management and implications for greenhouse gas emissions, biodiversity and water (SEPA 2012). The scientists concluded that "the highest biodiversity in a managed landscape can be expected when a high variation of forestry methods is applied. [...] Selective cutting is not necessarily a key-method for preserving biodiversity but will favor certain groups, e.g. shade and continuity depending species." (SEPA 2012, p. 21). In this report two publications from our list derived from WoS CC on GTR were cited, which focused on the ecological effects of GTR (Hautala et al. 2004; Matveinen-Huju et al. 2006). Results from both projects were later included in an official report (SOU 2013:43) which lay the foundation for a new bill (Gov. Bill 2013/2014:141, see next section).

A new public investigation of the Forestry Act presented in 2006 (SOU 2006:81) further discussed and promoted increased use of CCF methods as a complement to clear-cut forestry in Swedish forests. The investigator emphasized the importance of CCF at the SFA (SOU 2006:81), but did not directly refer to scientific publications, but instead cited reviews and popular syntheses that primarily addressed silvicultural aspects of CCF (e.g. from Formas and Skogforsk, SOU 2006:81).

\section{Third loop: selection of policy options and implementation}

In the third loop, parliamentary discussions regarding CCF increased (Fig. 5). At this stage the government and the SFA did not present stronger instruments for the implementation of $\mathrm{CCF}$, but instead clarified legislation about legal harvest methods to overcome formal institutional uncertainty (Gov.Bill 2007/2008:108; Gov. Bill 2013/2014:141; SKSFS 2015:3). In educational handbooks, silvicultural scientists acknowledged CCF as "a gentler way to manage forest" (Lundqvist et al. 2014, p. 49). The government subsequently allocated funds to the SFA for the development of CCF methods and related advice to forest owners (Gov. Bill 2017/2018:1), but it still remained undecided as to whether additional policy instruments besides communication and education were needed to accelerate CCF implementation (SEPA 2017). Since 2010, the Swedish FSC standard explicitly supports $\mathrm{CCF}$ as a way to sustain ecological functions and values in forest stands possessing suitable 
conditions (FSC 2010b). The PEFC ${ }^{2}$ standard is more reluctant regarding CCF, stating that the scientific basis for CCF management is weak, but that CCF methods may be used with caution under certain conditions (PEFC 2017).

To date, the GTR policy remains unchanged, but the long-standing requirement to leave at least ten green trees $\mathrm{ha}^{-1}$ has been questioned, since this small number of trees is not assumed to be motivated by scientific ecological knowledge (WWF 2017; referring Fedrowitz et al. 2014). Nevertheless, due to the use of several weak and strong policy instruments, trees left in young forests have increased during the 1990s and seemingly stabilized during the 2000s (Fig. 1). As of 2007, on average 11 living trees $\mathrm{ha}^{-1}$ were being retained 5-7 years after regeneration felling (SFA 2007). Thus far CCF has however only been implemented to such a limited extent that no reliable national statistics are currently available. However, common knowledge within the forestry sector suggests that the method has rarely been used since large-scale mechanized forestry developed in the 1950s. According to official data from 2013, large forest owners (owning more than 5000 ha) planned to manage $<1 \%$ of productive forests (excluding set-asides) with CCF methods (SFA 2013).

\section{Discussion}

\section{Ecological and other scientific knowledge as promotors or obstacles}

Our assessment of GTR and CCF policy uptake and implementation revealed that GTR and CCF underwent three loops over almost five decades and eventually resulted in the widespread implementation of GTR, while CCF implementation has hardly advanced. During all loops of the policy cycle, scientific ecological knowledge has helped push conservation measures forward. Ecological scientists provided input to problem formulation stages, and were invited by the government, together with other knowledge producers and stakeholders, to contribute to investigations and help evaluate policy options. In this regard, the policy uptake of theoretical and general ecological knowledge for both GTR and CCF was already taking place in the 1970s (e.g. SEPA 1972; Ahlén 1977). However, limited research had been performed at this time to address the actual effects of GTR and CCF on forest species. Hence, GTR was selected as a policy option, despite a lack of scientific evidence regarding its ecological effects (Fig. 3a). In contrast CCF was neglected in policy, despite available evidence underscoring the importance of spatial and temporal continuity in tree cover for forest-dependent species (e.g. Ahlén 1977).

Over the intervening decades a growing body of knowledge demonstrated the positive effects that both GTR and CCF can have for many elements of forest biodiversity, as well as for the ecological structure and function of forest ecosystems (e.g. Fedrowitz et al. 2014; Kuuluvainen et al. 2012). Nevertheless, both GTR and CCF lack studies on their longterm and landscape-level effects on biodiversity (Fedrowitz et al. 2014; Kuuluvainen et al. 2012). For this reason, knowledge gaps are still used as an argument when discussing to which extent these measures should be applied (e.g. SFA 2019).

Interestingly, our analysis showed how scientists provided quantitative recommendations regarding GTR in the early 1990s (Ingelög and Lennartsson 1991) and that analogous targets were included in both formal GTR policy and the certification schemes of the 1990s. We know from previous studies that policy makers desire science-based information about quantitative

\footnotetext{
2 Programme for the Endorsement of Forest Certification Schemes (PEFC), was introduced in Sweden in 2000 as a certification scheme for family forest owners.
} 
requirements for biodiversity (Gulbrandsen 2008; Angelstam et al. 2013). Ecological scientists are however reluctant to deliver such precise recommendations and targets are often left to be negotiated by stakeholders involved in the policy processes (Ranius et al. 2017). The example of policy uptake of GTR indicates how compelling such recommendations can be.

We found that the type of research conducted on CCF has been broader than that for GTR, including more silvicultural and economic studies (Fig. 3). Despite these efforts, the economic outcomes of CCF are still regarded as uncertain (Kuuluvainen et al. 2012). Knowledge regarding economic uncertainty has continued to be an obstacle, not only to the progress of CCF within the formal policy cycle (e.g. SFA 2008; Lundqvist et al. 2014), but also in terms of certification standards for which CCF remains an "interesting" but uncertain silvicultural alternative (PEFC 2017).

\section{Formal institutional factors as obstacles or promotors}

The implementation of GTR depended on complex processes of socio-political negotiations involving actors inside as well as outside the formal policy making procedures. There were no formal institutional obstacles to GTR uptake in the 1970s and the government used judicial and communicative policy instruments to promote GTR in the 1970s and 1980s (e.g. SKSFS 1979:3; Ingelög 1981).

Economic instruments, such as subsidies or levies, were not selected to promote the implementation of GTR. However, in both 1979 and 1983, and concurrent with the new conservation efforts, the Swedish parliament increased production targets, first under the leadership of a coalition government of liberals and conservatives, and later by social democrats. Both law enforcement and financial incentives were used as policy instruments to steer private forest owners into efficient clear-cut forestry with the compulsory felling of mature forests and the afforestation of "forest with low annual increment", including species rich grazed woodland. The production-oriented policy objectives were thus stronger at that time and were invoked by more coercive legislation and subsidies (Bush 2010; Siiskonen 2013). The use of economic subsidies for production targets culminated in the mid-1980s (Siiskonen 2013) and the average number of trees retained at clearcutting was at its lowest from 1985 to 1989 (Fig. 1).

We believe that this strong orientation towards production forestry had an impact on the norms regarding conservation measures, i.e. ideas about what was important and what should be done, and indirectly countered the uptake of GTR for over a decade (Fig. 1; cf. Nylund 2009; Siiskonen 2013). In the 1990s, the third-party forest certification schemes effectively added economic incentives for the implementation of GTR (Johansson 2013). The revised forest legislation in 1993 also made GTR mandatory and both forest certification and public policy provided quantitative goals for implementation (SKSFS 1993:2).

In contrast, CCF was met with institutional obstacles until the 1990s, and only in recent years was formal legislation sufficiently reformed to allow for the active promotion of CCF (SKSFS 2015:3). Notably, whereas forest certification schemes are supportive of CCF, this support is still limited to certain forest contexts, and there are no stated goals for the level of implementation (FSC 2010b; PEFC 2017).

\section{Normative factors as obstacles or promotors}

The lack of GTR implementation in the 1980s was, as mentioned earlier, affected by normative obstacles. According to contemporary investigations, there was a general 
consensus in Sweden at that time regarding the importance of conserving threatened species (Eckerberg 1987), but production interests were nevertheless stronger (cf. Siiskonen 2013). The means and costs of conserving threatened species were disputed, and even the retention of single trees on a clear cut was sometimes regarded as too much of a sacrifice for a forest owner (Eckerberg 1987). With the support of education, legislation and market-based certification, the concept of GTR slowly became a norm in Swedish forestry and it is today regarded as a key component of the "Swedish forestry model" (KSLA 2009).

In contrast to GTR, and consistent with our findings for formal institutional obstacles, CCF encountered substantial normative obstacles until recently, with these obstacles built upon cultural and historical experiences (cf. Puettmann et al. 2015). Potentially as a result of these obstacles, since 2010 the term "clear cut free forestry" has dominated the governmental discourse and gradually replaced the term "continuous-cover forestry" (Fig. 5). In a Swedish context, this new term might have helped to overcome some of the normative obstacles connected to CCF. More specific silvicultural approaches within the CCF framework, e.g., "selective cutting", have had a bad reputation among foresters for almost a century. This reputation stem from foresters experiencing failures in selective cuttings in the early $20^{\text {th }}$ century, which resulted in forest stands with low levels of regeneration and productivity (e.g. Ds Jo 1974:2, 204; Lundqvist et al. 2014). Thus, the Swedish norm formulated in the mid-twentieth century, whereby rationalized forestry would deliver a high and even yield of biomass to secure public welfare (Mårald et al. 2017), still remains strong among opponents of CCF.

\section{Strategic factors as obstacles or promotors}

Our assessment of strategic factors revealed a path from uncertainty to a lack of substantial obstacles for GTR, whereas CCF's path has progressed from strong to uncertain obstacles during the same time period. We suggest that GTR became regarded as a beneficial strategy in the late 1980s, when forest companies started to develop GTR policies and worked together with the SFA to provide inventories, evaluations, and educational programs. GTR was probably regarded as a feasible and cost-effective strategy to counter pressure from the environmental movement and other actors, including ecological scientists, and as a means to reduce the likelihood of stronger formal governmental regulations (cf. Doelen 1998; Simonsson et al. 2014). With certification agencies promoting GTR, it became even more strategic to adopt GTR at final harvest.

Relatively few factors have been in place for CCF adoption to be a strategic silvicultural approach for forest owners. In comparison, the logistics and streamlined efficiency of clearcutting continues to hamper CCF implementation (cf. Axelsson 2008). It is not surprising therefore, that recent surveys show a strong continued support for even-aged management among family forest owners (Nordén et al. 2017). Family forest owner associations are also setting the standards for PEFC (Johansson 2013). Thus, large-scale initiatives to implement $\mathrm{CCF}$ are not expected in the near future, with uptake likely limited in area and specific contexts linked to conservation or other societal goals.

\section{Conclusions}

We found that ecological scientists provided important input to the development of conservation policy and practice at almost every stage in the analysed policy cycle and its three loops, from year 1971 to 2017. They offered their expertise in governmental and agency 
reports, co-produced educational handbooks and communicated demands directly to the politicians. However, knowledge from other research disciplines and socio-political factors were also important, which helps to explain why CCF is still only rarely applied. In the case of GTR, uptake was enhanced by its consistency with the silvicultural knowledge and normative values that forest managers and owners had adopted for almost a century, whereas CCF challenged those ideas.

Acknowledgements Open access funding provided by Umea University. The authors are grateful for input and comments provided by scientists and practitioners at earlier stages of this manuscript. We also thank two anonymous reviewers for their valuable comments. This study was entirely funded through Future Forests, a multi-disciplinary research programme supported by the Foundation for Strategic Environmental Research (MISTRA), the Swedish Forestry Industry, the Swedish University of Agricultural Sciences (SLU), Umeå University, and the Forestry Research Institute of Sweden. The funding sources had no involvement in the study design, collection, analysis or interpretation of data; in writing or decision to submit the article for publication. The authors declare no conflict of interest.

Data availability The research publications data that support the findings of this study are available from Clarivate Analytics Web of Science Core Collection, http://apps.webofknowledge.com and within the article's two appendices. Policy documents data are available from the Swedish Parliament, the Riksdag's Open Data, http://data.riksdagen.se/In-English/. Further information about the analysed data sets is available on request from the corresponding author (AS).

Open Access This article is distributed under the terms of the Creative Commons Attribution 4.0 International License (http://creativecommons.org/licenses/by/4.0/), which permits unrestricted use, distribution, and reproduction in any medium, provided you give appropriate credit to the original author(s) and the source, provide a link to the Creative Commons license, and indicate if changes were made.

\section{Appendix 1}

\section{Search string for scientific publications on green tree retention (GTR)}

The terms for "Management" are taken from various sources including Fedrowitz and Gustafsson 2012 and others. The terms for "Geography" are from Kuuluvainen et al. (2012) plus a few additional terms (italics). Terms within a given column were separated by "OR" in the search string.

\begin{tabular}{|c|c|c|c|c|}
\hline Relevance to forest & & Management & & Geography \\
\hline Forest* & AND & $\begin{array}{l}\text { Alternative cut* } \\
\text { Alternative felling* } \\
\text { Alternative harvest* } \\
\text { Ancient tree* } \\
\text { Biological legac* } \\
\text { Green tree retention* } \\
\text { Green tree* } \\
\text { Long-term retention* } \\
\text { Remnant tree* } \\
\text { Residual tree* } \\
\text { Retention tree* } \\
\text { Retention threshold* }\end{array}$ & AND & $\begin{array}{l}\text { Fennoscand* } \\
\text { Scandinav* } \\
\text { Finland } \\
\text { Finnish } \\
\text { Swed* } \\
\text { Norw* } \\
\text { Murmansk } \\
\text { Karelia* } \\
\text { Leningrad } \\
\text { Petersburg }\end{array}$ \\
\hline
\end{tabular}




\begin{tabular}{lll}
\hline Relevance to forest & Management & Geography \\
\hline & Structural retention* \\
& Variable retention* \\
& Veteran tree* \\
\hline
\end{tabular}

Search string in text form

forest* AND ("alternative cut*" OR "alternative felling*" OR "alternative harvest*" OR "ancient tree*" OR "biological legacy*" OR "green tree*" OR "green tree retention*" OR "long-term retention*" OR "remnant tree*" OR "residual tree*" OR "retention threshold*" OR "structural retention*" OR "variable retention*" OR "veteran tree*" AND (Fennoscand* OR Scandinav* OR Finland OR Finnish OR Swed* OR Norw* OR Murmansk OR Karelia* OR Leningrad OR Petersburg)

Database: Web of Science Core Collection

\section{Appendix 2}

\section{Search string for scientific publications on continuous cover forestry (CCF)}

Search string. The terms for "Management" and "Geography" are from Kuuluvainen et al. (2012) plus a few additional terms (italics). Terms within a given column were separated by "OR" in the search string.

\begin{tabular}{|c|c|c|c|c|}
\hline Relevance to forest & & Management & & Geography \\
\hline Forest* & AND & $\begin{array}{l}\text { Alternative cut* } \\
\text { Alternative felling* } \\
\text { Alternative harvest* } \\
\text { Clearcut free } \\
\text { Clear cut free } \\
\text { Continuous cover } \\
\text { Gap cut* } \\
\text { Gap felling* } \\
\text { Gap harvest* } \\
\text { Partial cut* } \\
\text { Partial felling* } \\
\text { Partial harvest* } \\
\text { Selection cut* } \\
\text { Selection felling* } \\
\text { Selection harvest* } \\
\text { Single tree select* } \\
\text { Uneven age* } \\
\text { Uneven size* }\end{array}$ & AND & $\begin{array}{l}\text { Fennoscand* } \\
\text { Scandinav* } \\
\text { Finland } \\
\text { Finnish } \\
\text { Swed* } \\
\text { Norw* } \\
\text { Murmansk } \\
\text { Karelia* } \\
\text { Leningrad } \\
\text { Petersburg }\end{array}$ \\
\hline
\end{tabular}

Search string in text form

forest* AND ("alternative cut*" OR "alternative felling*" OR "alternative harvest*" OR "clearcut free" OR "clear cut free" OR "continuous cover" OR "gap cut*" OR "gap felling*" OR "gap harvest*" OR "partial cut*" OR "partial felling*" OR "partial harvest*" OR "selection cut*" OR "selection felling*" OR "selection harvest*" OR "single tree select*" OR "uneven age*" OR "uneven size*") AND (Fennoscand* OR Scandinav* OR Finland OR Finnish OR Swed* OR Norw* OR Murmansk OR Karelia* OR Leningrad OR Petersburg)

Database: Web of Science Core Collection 


\section{References}

Ahlén I (1977) Faunavård: om bevarande av hotade djurarter i Sverige. Liber Förlag, Vällingby

Ahlén I, Boström U, Ehnström B, Pettersson B (1979) Faunavård i skogsbruket: allmän del. Skogsstyrelsen, Jönköping

Aldentun Y, Drakenberg B, Lindhe A (1991) Naturhänsyn i skogen. Forskningsstiftelsen Skogsarbeten, Kista

Andreassen K, Yen B (2002) Economic consequences of three silvicultural methods in unevenaged mature coastal spruce forests of central Norway. Forestry 75:483-488

Angelstam P, Andersson L (1997) I vilken omfattning behöver arealen skyddad skog i Sverige utökas för att biologisk mångfald skall bevaras? SOU 1997:98. Bilaga 4

Angelstam P, Roberge J-M, Axelsson R, Elbakidze M, Bergman K-O, Dahlberg A, Degerman E, Eggers S, Esseen P-A, Hjältén J, Johansson T, Müller J, Paltto H, Snäll T, Soloviy I, Törnblom J (2013) Evidencebased knowledge versus negotiated indicators for assessment of ecological sustainability: The Swedish Forest Stewardship Council Standard as a case study. Ambio 42:229-240

Axelsson R (2008) Forest policy, continuous tree cover forest and uneven-aged forest management in Sweden's boreal forest. Dissertation, Swedish University of Agricultural Sciences

Axelsson R, Angelstam P (2011) Uneven-aged forest management in boreal Sweden: local forestry stakeholders' perceptions of different sustainability dimensions. Forestry 84:567-579

Bergqvist J, Eriksson A, Fries C (2011) Polytax 5/7 regeneration taxation: results from 1999-2009 [In Swedish: Polytax 5/7 återväxttaxering: resultat från 1999 - 2009]. Report 1, Swedish Forest Agency

Gov. Bill 1974:166. Kungl. Maj:ts proposition med förslag till ändringar i naturvårdslagen (1964:822) och skogsvårdslagen (1948:237), m.m. Sveriges Riksdag. https://www.riksdagen.se/sv/dokument-lagar/dokument/ proposition/kungl-majts-proposition-med-forslag-till_FX03166. Accessed 29 Jan 2019

Gov. Bill 1978/1979:110 Om riktlinjer för skogspolitiken m.m. Sveriges Riksdag. Sveriges Riksdag. https://www. riksdagen.se/sv/dokument-lagar/dokument/proposition/om-riktlinjer-for-skogspolitiken-mm_G203110. Accessed 10 May 2019

Gov. Bill 1992/1993:226. Om en ny skogspolitik. Sveriges Riksdag. https://www.riksdagen.se/sv/dokument-lagar /dokument/proposition/om-en-ny-skogspolitik_GG03226. Accessed 29 Jan 2019

Gov. Bill 2007/2008:108. En skogspolitik i takt med tiden. Sveriges Riksdag. https://www.riksdagen.se/sv/dokum ent-lagar/dokument/proposition/en-skogspolitik-i-takt-med-tiden_GV03108. Accessed 29 Jan 2019

Gov. Bill 2013/2014:141. En svensk strategi för biologisk mångfald och ekosystemtjänster. Sveriges Riksdag. https://www.riksdagen.se/sv/dokument-lagar/dokument/proposition/en-svensk-strategi-for-biologiskmangfald-och_H103141. Accessed 29 Jan 2019

Gov. Bill 2017/2018:1. Budgetproposition för 2018. Sveriges Riksdag. https://www.riksdagen.se/sv/dokumentlagar/dokument/proposition/budgetpropositionen-for-2018_H5031. Accessed 29 Jan 2019

Bush T (2010) Biodiversity and sectoral responsibility in the development of Swedish forestry policy, 1988-1993. Scand J Hist 35:471-498

Ds Jo 1974:2. Kalhyggen. Rapport avgiven av en arbetsgrupp inom Jordbruksdepartementet. Jordbruksdepartementet, Stockholm

Eckerberg K (1987) Environmental protection in Swedish forestry: a study of the implementation process. Dissertation, Umeå University

Ehnström B, Waldén HW (1986) Faunavård i skogsbruket. D. 2, Den lägre faunan. Skogsstyrelsen, Jönköping

Enander K-G (2007) Ekologi, skog och miljö: vetenskap och idéer under 300 år. Sveriges lantbruksuniversitet, Umeå

Esseen P, Ehnström B, Ericson L, Sjöberg K (1992) Boreal forests-the focal habitats of Fennoscandia. In: Hansson L (ed) Ecological principles of nature conservation. Elsevier Applied Science, London, pp 252-325

FAO (2016) Global forest resources assessment: how are the world's forests changing 2015? Second edition. Food and agricultural association of the united nations, Rome. http://www.fao.org/3/a-i4793e.pdf. Accessed 26 July 2018

Fedrowitz K, Koricheva J, Baker SC, Lindenmayer DB, Palik B, Rosenvald R, Beese W, Franklin JF, Kouki J, Macdonald E, Messier C, Sverdrup-Thygeson A, Gustafsson L (2014) Can retention forestry help conserve biodiversity? A meta-analysis. J Appl Ecol 51:1669-1679

Felton A, Nilsson U, Sonesson J et al (2016) Replacing monocultures with mixed-species stands: ecosystem service implications of two production forest alternatives in Sweden. Ambio 45:124-139

Franklin J (1989) Toward new forestry. Am For 95:37-44

FSC (2010a) Jämförelse. Svensk skogsbruksstandard enligt FSC. 1998 års standard (V1) och 2010 års standard (V2-1). Svenska FSC:s kansli 2010-05-14

FSC (2010b) FSC Forest Management standard for Sweden. FSC-STD-SWE-02-03-2010 Sweden Natural, Plantations and SLIMF. https://se.fsc.org/preview.fsc-forest-management-standard-for-sweden.a-772. pdf. Accessed 26 July 2018 
Gärdenfors U (1997) Fördelning av arter i olika skogsbiotoper i Sverige. SOU 1997:98. Bilaga 5. https:// data.riksdagen.se/fil/2A4CB674-09E7-4063-B235-80E99920F388. Accessed 29 Jan 2019

Granhus A, Fjeld D (2001) Spatial distribution of injuries to Norway spruce advance growth after selection harvesting. Can J For Res 31:1903-1913

Gulbrandsen LH (2008) The role of science in environmental governance: competing knowledge producers in Swedish and Norwegian forestry. Glob Environ Polit 8:99-122

Gustafsson L, Baker SC, Bauhus J, Beese W, Brodie A, Kouki J, Lindenmeyer DB, Lohmus A, Pastur GM, Messier C et al (2012) Retention forestry to maintain multifunctional forests: a world perspective. Bioscience 62:633-645

Haas P (2004) When does power listen to truth? A constructivist approach to the policy process. J Eur Publ Pol 11:569-592. https://doi.org/10.1080/1350176042000248034

Hallerstig P (1998) Sammanfattning av Skogsvårdsorganisationens utvärdering av skogspolitiken. Kungl. Skogs- och lantbruksakademiens tidskrift no 9, 137:25-36

Hautala H, Jalonen J, Laaka-Lindberg S, Vanha-Majamaa I (2004) Impacts of retention felling on coarse woody debris (CDW) in mature boreal spruce forests in Finland. Biodivers Conserv 13:1541-1554

Hays SP (2007) Wars in the Woods: The Rise of Ecological Forestry in America. University of Pittsburgh Press, Pittsburgh

Howlett M, McConnell A, Perl A (2015) Streams and stages: reconciling Kingdon and policy process theory. Eur J Polit Res 54:419-434

Ingelög T (ed) (1981) Floravård i skogsbruket: allmän del. Skogsstyrelsen, Jönköping

Ingelög T (2007) ArtDatabanken: en resa från 70-talets kalhyggesdebatt till dagens Nationalnyckel. In: Ramberg G (ed) SLU: tre decennier mitt i samhällsutvecklingen. Swedish University of Agricultural Sciences, Uppsala, pp 257-269

Ingelög T, Lennartsson T (1991) Åtgärder för att stärka biologisk mångfald i odlings- och skogslandskap: idékatalog för beslutsfattare. Swedish University of Agricultural Sciences, Uppsala

Ingelög T, Thor G, Gustafsson L (1984) Floravård i skogsbruket. D. 2, Artdel. Skogsstyrelsen, Jönköping

Jann W, Wegrich K (2007) Theories of the policy cycle. In: Fischer F, Miller G, Sidney M (eds) Handbook of public policy analysis. CRC Press, New York, pp 43-62

Jasanoff S (2004) Ordering knowledge, ordering society. In: Jasanoff S (ed) States of knowledge: the coproduction of science and social order. Routledge, London, pp 13-43

Johansson J (2013) Constructing and contesting the legitimacy of private forest governance: the case of forest certification in Sweden. Dissertation, Umeå university

Jonsson P, Sörlin S (2002) Mångfald i forskningslandskapet - grundforskning och extern finansiering vid SLU. In: Sandström U (ed) Det nya forskningslandskapet: perspektiv på vetenskap och politik. Nya Doxa, Stockholm, pp 109-132

JoU 1979. Jordbruksutskottets betänkande 1978/1979:JoU30. Sveriges Riksdag. https://www.riksdagen.se/ sv/dokument-lagar/arende/betankande/med-anledning-av-propositionen-197879110-om_G201JoU30. Accessed 10 May 2019

Kruys N, Fridman J, Götmark F, Simonsson P, Gustafsson L (2013) Retaining trees for conservation at clearcutting has increased structural diversity in young Swedish production forests. For Ecol Manage 304:312-321. https://doi.org/10.1016/j.foreco.2013.05.018

KSLA (2009) The Swedish forestry model. The Royal Swedish Academy of Agriculture and Forestry (KSLA), Stockholm. http://www.ksla.se/wp-content/uploads/2010/10/The-Swedish-Forestry-Model .pdf. Accessed 29 Jan 2019

Kuuluvainen T, Tahvonen O, Aakala T (2012) Even-aged and uneven-aged forest management in boreal Fennoscandia: a review. Ambio 41:720-737

Lawrence A (2017) Adapting through practice: silviculture, innovation and forest governance for the age of extreme uncertainty. For Policy Econ 79:50-60

Lidskog R, Löfmarck E (2015) Managing uncertainty: forest professionals' claim and epistemic authority in the face of societal and climate change. Risk Manag 17:145-164

Lidskog R, Sjödin D (2014) Why do forest owners fail to heed warnings? Conflicting risk evaluations made by the Swedish Forest Agency and forest owners. Scand J For Res 29:275-282. https://doi. org/10.1080/02827581.2014.910268

Lundgren LJ (1998) Acid rain on the agenda: a picture of a chain of events in Sweden, 1966-1968. Lund University Press, Lund

Lundqvist L, Cedergren J, Eliasson L (2014) Blädningsbruk. Skogsskötselserien. Skogsstyrelsen, Jönköping Mårald E, Sandström C, Nordin A et al (2017) Forest governance and management across time: developing a new forest social contract. Routledge, New York 
Mason W, Kerr G, Simpson J (1999) What is continuous cover forestry? Information note. Forestry Commission, Edinburgh. https://www.forestresearch.gov.uk/research/archive-what-is-continuous-cover -forestry/. Accessed 10 May 2019

Matthews JD (1989) Silvicultural systems. Clarendon Press, Oxford

Matveinen-Huju K, Niemel J, Rita H, O'Hara RB (2006) Retention-tree groups in clear-cuts: do they constitute 'life-boats' for spiders and carabids. Forest Ecol Manag 230:119-135

May JV, Wildavsky AB (1978) The policy cycle. Sage, Beverly Hills

Mot. 1971:1002 Angående det moderna skogsbrukets konsekvenser från miljösynpunkt. Sveriges Riksdag. https://www.riksdagen.se/sv/dokument-lagar/dokument/motion/angaende-det-moderna-skogsbruketskonsekvenser_FU021002. Accessed 10 May 2019

Mot. 1972:146 Angående kalhuggning av skog. Sveriges Riksdag. https://www.riksdagen.se/sv/dokumentlagar/dokument/motion/angaende-kalhuggningen-av-skog_FV02146. Accessed 10 May 2019

Mot. 1990/1991:Jo731 Naturvård. Sveriges Riksdag. https://www.riksdagen.se/sv/dokument-lagar/dokum ent/motion/naturvard_GE02Jo731. Accessed 10 May 2019

Mot. 1990/1991:Jo306 Skogen. Sveriges Riksdag. https://www.riksdagen.se/sv/dokument-lagar/dokument/ motion/skogen_GE02Jo306. Accessed 10 May 2019

Mot. 1990/1991:Jo311 Skogsbruk. Sveriges Riksdag. https://www.riksdagen.se/sv/dokument-lagar/dokum ent/motion/skogsbruk_GE02Jo311. Accessed 10 May 2019

Nagasaka K, Böcher M, Krott M (2016) Are forest researchers only scientists? Case studies on the roles of researchers in Japanese and Swedish forest policy processes. For Policy Econ 70:147-154

Nordén A, Coria J, Jönsson AM, Lagergren F, Lehsten V (2017) Divergence in stakeholders' preferences: evidence from a choice experiment on forest landscapes preferences in Sweden. Ecol Econ 132:179-195

North R, Chen J, Smith G, Krakowiak L, Franklin J (1996) Initial response of understory plant diversity and overstory tree diameter growth to a green tree retention harvest. Northwest Sci 70:24-35

Nylund J-E (2009) Forestry legislation in Sweden. Swedish University of Agricultural Sciences, Uppsala. https://pub.epsilon.slu.se/5503/1/Forestry_legislation_in_Sweden.pdf. Accessed 28 July 2018

Parsons W (1995) Public policy: an introduction to the theory and practice of policy analysis. Elgar, Aldershot

PEFC 2017. PEFC SWE 001:4 Svenska PEFCs certifieringssystem 2017-12-15. Swedish PEFC. http://pefc. se/wp-content/uploads/2017/12/PEFC-SWE-001-Svenska-PEFCs-certifieringssystem-2017-12-15. pdf. Accessed 27 July 2018

Persson J, Ek B, Holmer M, Nordanstig G (1990) Rikare skog: 90-talets kunskaper om naturvård och ekologi. Skogsstyrelsen, Jönköping

Pommerening A, Murphy S (2004) A review of the history, definitions and methods of continuous cover forestry with special attention to afforestation and restocking. Forestry 77:27-44

Puettmann K, Wilson J, Baker S, Donoso M, Drössler S, Amente C, Bauhus Y (2015) Silvicultural alternatives to conventional even-aged forest management—what limits global adoption? For Ecosyst 2:1-16

Pullin AS, Knight TM (2003) Support for decision making in conservation practice: an evidencebased approach. J Nat Conserv 11:83-90. https://doi.org/10.1078/1617-1381-00040

Ranius T, Rudolphi J, Sténs A, Mårald E (2017) Conflicting demands and shifts between policy and intrascientific orientation during conservation research programmes. Ambio 46:621-629

Riksdagen (2019) What do the Riksdag do? Sveriges Riksdag. http://riksdagen.se/en/how-the-riksdagworks/what-does-the-riksdag-do/makes-laws/. Accessed 10 May 2019

Rosenvald R, Lõhmus A (2008) For what, when, and where is green-tree retention better than clear-cutting? A review of the biodiversity aspects. For Ecol Manage 255:1-15

Salomaa A, Paloniemi R, Hujala T, Rantala S, Arponen A, Niemelä J (2016) The use of knowledge in evidence-informed voluntary conservation of Finnish forests. For Policy Econ 73:90-98. https://doi. org/10.1016/j.forpol.2016.09.004

SEPA (Swedish Environmental Protection Agency) (1972) Skogsbruket och naturvården. Statens naturvårdsverk, Stockholm

SEPA (Swedish Environmental Protection Agency) (2012) Land management meeting several environmental objectives: minimizing impacts on greenhouse gas emissions, biodiversity and water. Report 6505. Naturvårdsverket, Stockholm

SEPA (Swedish Environmental Protection Agency) (2017) Miljömålen: årlig uppföljning av Sveriges nationella miljömål. Naturvårdsverkets rapport 6749. Naturvårdsverket, Stockholm

SFA (Swedish Forest Agency) (1991) Tagen hänsyn vid slutavverkningar 1989-91. Meddelande 1991:4. Skogsstyrelsen, Stockholm

SFA (Swedish Forest Agency) (1998) Miljöhänsyn vid föryngringsavverkning: delresultat från Polytax. Skogsstyrelsen, Jönköping 
SFA (Swedish Forest Agency) (2004) Kontinuitetsskogar: en förstudie. Skogsstyrelsen, Jönköping

SFA (Swedish Forest Agency) (2007) Number of conservation trees left on net area, 3-years average. Surveyed 5-7 years after regeneration cutting by Region, Tree species and Year. http://pxweb .skogsstyrelsen.se/pxweb/en/Skogsstyrelsens\%20statistikdatabas/Skogsstyrelsens\%20statistikdata bas__Miljohansyn/JO1403_4a.px/chart/chartViewLine/?rxid=a01d8384-a717-4706-80e6-9cda5 612fd53. Accessed 25 July 2018

SFA (Swedish Forest Agency) (2008) Kontinuitetsskogar och hyggesfritt skogsbruk. Skogsstyrelsen, Jönköping. https://shopcdn.textalk.se/shop/9098/art63/4646163-1d8376-1809.pdf. Accessed 25 July 2018

SFA (Swedish Forest Agency) (2013) Area of continuous cover forestry in large-scale forestry, by ownership classes. Swedish Forest Agency; survey on large-scale forestry

SFA (Swedish Forest Agency) (2019) Hyggesfritt skogsbruk. https://www.skogsstyrelsen.se/bruka-skog/ olika-satt-att-skota-din-skog/hyggesfritt-skogsbruk/. Accessed 10 May 2019

SFS (Svensk Författningssamling) 1974:1026. Om ändring i skogsvårdslagen 1948:237. Liber, Stockholm

Siiskonen H (2007) The conflict between traditional and scientific forest management in 20th century Finland. For Ecol Manage 249:125-133

Siiskonen H (2013) From economic to environmental sustainability: the forest management debate in 20th century Finland and Sweden. Environ Dev Sustain 15:1323-1336

Simonsson P, Gustafsson L, Östlund L (2014) Retention forestry in Sweden: driving forces, debate and implementation 1968-2003. Scand J For Res 30:154-173. https://doi.org/10.1080/02827 581.2014.968201

Skr. 2003/2004:39 Uppföljning av skogspolitiken. Sveriges Riksdag. https://www.riksdagen.se/sv/dokum ent-lagar/dokument/skrivelse/uppfoljning-av-skogspolitiken_GR0339. Accessed 10 May 2019

SKSFS 1979:3 (1979) Skogsstyrelsens författningssamling. SKSFS. 1979:3, Föreskrifter m m till skogsvårdslagen. Norstedts, Stockholm

SKSFS 1993:2 (1993) Skogsstyrelsens författningssamling. Skogsstyrelsens föreskrifter m.m. till skogsvårdslagen. Norstedts, Stockholm

SKSFS 2015:3. Skogsstyrelsens föreskrifter och allmänna råd till Skogsvårdslagen. SKSFS 2011:7. Skogsstyrelsen, Jönköping. https://www.skogsstyrelsen.se/globalassets/lag-och-tillsyn/grundfores krifter-samt-andringar/sksfs-2011-7/sksfs-2015-2-foreskrifter-om-andring-i-skogsstyrelsens-fores krifter-sksfs-2011-7-och-allmanna-rad-till-skogsvardslagen.pdf. Accessed 10 May 2019; About the changes: http://databas.infosoc.se/lag/3814/andringar\#!. Accessed 10 May 2019

SOU 1992:76 Skogspolitiken inför 2000-talet huvudbetänkande. National Library of Sweden. http:// regina.kb.se/sou/. Accessed 10 May 2019

SOU 1992:76 Skogspolitiken inför 2000-talet huvudbetänkande. Bilagor II. National Library of Sweden. http://regina.kb.se/sou/. Accessed 10 May 2019

SOU 1997:97 Skydd av skogsmark: behov och kostnader: huvudbetänkande. National Library of Sweden. http://regina.kb.se/sou/. Accessed 10 May 2019

SOU 1997:98 Skydd av skogsmark: behov och kostnader. Bilagor. National Library of Sweden. http:// regina.kb.se/sou/. Accessed 10 May 2019

SOU 2006:81 Mervärdesskog. National Library of Sweden. http://regina.kb.se/sou/. Accessed 10 May 2019

SOU 2013:43 Långsiktigt hållbar markanvändning. Sveriges Riksdag. https://www.regeringen.se/ratts liga-dokument/statens-offentliga-utredningar/2013/06/sou-201343/. Accessed 10 May 2019

SUS 2001 (2002) Skogsvårdsorganisationens utvärdering av politikens effekter. Skogsstyrelsen, Jönköping https://shopcdn.textalk.se/shop/9098/art61/4645961-0b0ef8-1544.pdf. Accessed 10 May 2019

van der Doelen FCJ (1998) The 'give-and-take' packaging of policy instruments: optmizing legitimacy and effectiveness. In: Bemelans-Videc M-L, Rist RC, Vedung E (eds) Carrots, sticks \& sermons. Transaction Publishers, New Brunswick, pp 129-146

van Kerkhoff L, Lebel L (2006) Linking knowledge and action for sustainable development. Annu Rev Environ Resour 31:445-477

Vedung E (1998) Policy instruments: typologies and theories. In: Bemelans-Videc M-L, Rist RC, Vedung E (eds) Carrots, sticks \& sermons. Transaction Publishers, New Brunswick, pp 21-58

Wallin I (2017) Forest management and governance in Sweden. Dissertation, Swedish University of Agricultural Sciences

Wellock TR (2010) The dickey bird scientists take charge: science, policy, and the spotted owl. Environ Hist $15: 381-414$

WWF (2017) Remissvar: Nya och reviderade målbilder för god miljöhänsyn. Swedish Forest Agency. https ://www.skogsstyrelsen.se/globalassets/om-oss/radgivande-grupper/samverkansgrupp-malbilder/remis svar-malbilder-2017/wwf.pdf. Accessed 28 July 2018 
Publisher's Note Springer Nature remains neutral with regard to jurisdictional claims in published maps and institutional affiliations.

\section{Affiliations}

\section{Anna Sténs ${ }^{1}$ D Jean-Michel Roberge $\mathrm{e}^{2,3} \cdot$ Erik Löfmarck $^{4} \cdot$ Karin Beland Lindahl $^{5}$. Adam Felton $^{6}$. Camilla Widmark ${ }^{7}$. Lucy Rist ${ }^{8}$. Johanna Johansson ${ }^{9}$. Annika Nordin ${ }^{10}$. Urban Nilsson ${ }^{6} \cdot$ Hjalmar Laudon ${ }^{8} \cdot$ Thomas Ranius $^{11}$}

Jean-Michel Roberge

jean-michel.roberge@skogsstyrelsen.se; jean-michel.roberge@slu.se

Erik Löfmarck

erik.lofmarck@oru.se

Karin Beland Lindahl

karin.beland.lindahl@ltu.se

Adam Felton

adam.felton@slu.se

Camilla Widmark

camilla.widmark@slu.se

Lucy Rist

lucyrist@gmail.com

Johanna Johansson

johanna.johansson@sh.se

Annika Nordin

annika.nordin@slu.se

Urban Nilsson

urban.nilsson@slu.se

Hjalmar Laudon

hjalmar.laudon@slu.se

Thomas Ranius

thomas.ranius@slu.se

1 Department of Historical, Philosophical and Religious Studies, Umeå University, 90187 Umeå, Sweden

2 Forest Unit, Swedish Forest Agency, Box 284, 90106 Umeå, Sweden

3 Department of Wildlife, Fish and Environmental Studies, Swedish University of Agricultural Sciences, 90183 Umeå, Sweden

4 Environmental Sociology Section, Örebro University, 70182 Örebro, Sweden

5 Department of Business Administration, Technology and Social Sciences, Luleå University of Technology, 971 87, Luleå, Sweden

6 Southern Swedish Forest Research Centre, Swedish University of Agricultural Sciences, Box 49, 23053 Alnarp, Sweden

7 Department of Forest Economics, Swedish University of Agricultural Sciences, 90183 Umeå, Sweden

8 Department of Forest Ecology and Management, Swedish University of Agricultural Sciences, 90183 Umeå, Sweden

9 School of Natural Sciences, Technology and Environmental Studies, Södertörn University, 
14189 Huddinge, Sweden

10 Department of Forest Genetics and Plant Physiology, Swedish University of Agricultural Sciences, 90183 Umeå, Sweden

11 Department of Ecology, Swedish University of Agricultural Sciences, Box 7044, 75007 Uppsala, Sweden 